Discussion Paper Series No.168

Foreign Outsourcing, Exporting, and FDI:

A Productivity Comparison at the Firm Level

Eiichi Tomiura Kobe University

February 2005

Discussion papers are a series of manuscripts in their draft form. They are not intended for circulation or distribution except as indicated by the author. For that reason Discussion Papers may not be quoted, reproduced or distributed without the written consent of the author. 


\title{
Foreign Outsourcing, Exporting, and FDI: A Productivity Comparison at the Firm Level
}

\author{
Eiichi Tomiura* \\ Research Institute for Economics and Business Administration, Kobe University
}

Current version: February 11, 2005

\begin{abstract}
This paper compares the productivity of firms active in foreign outsourcing, exporting, foreign direct investment, or only in domestic operations by a firm-level data of more than 118 thousand Japanese manufacturers. Only a small fraction of firms outsource, export, or invest across borders. The group averages, inter-firm distributions, regressions controlling for industry-effects, and multinomial response models unanimously demonstrate that FDI firms are distinctively more productive than foreign outsourcing firms, which are equally productive as exporters and are clearly more productive than domestic firms. Productive, innovative, or computerized firms are likely to globalize. The firms outsourcing overseas are particularly labor-intensive.
\end{abstract}

JEL Classifications: F12; F23; D20; F14.

Keywords: Productivity; Firm-level data; Exporter; Foreign outsourcing; FDI

\footnotetext{
* Eiichi Tomiura, Research Institute for Economics and Business Administration, Kobe University, 2-1 Rokko-dai, Nada, Kobe City, 657-8501, Japan. Phone: 81-(0)78-803-7008, Fax:

81-(0)78-803-7059, E-mail: tomiura@rieb.kobe-u.ac.jp.
} 


\section{Introduction}

Accelerated by trade liberalization and information technology development, more and more firms are active in trade and investment across national borders. However, only a small fraction of firms invest directly abroad, some firms export and/or outsource overseas, and the vast majority of firms sell all their output to domestic consumers and buy inputs totally from domestic suppliers even in industrialized countries. Theoretical models have recently incorporated this inter-firm heterogeneity in investigating the decision of firms to source abroad either through foreign outsourcing (FO) or foreign direct investment (FDI) (e.g. Antras and Helpman (2004)), and the firm's decision to serve foreign markets through exporting or FDI (e.g. Helpman et al. (2004)). These models, if combined, indicate that the high-productivity firms engage in FDI, the low-productivity firms are active only within the home country, and the firms with productivity in the intermediate range choose exporting in the sales decision and FO in the purchase decision. These theories of organizational mode choice have deepened our understanding of trade and FDI from the aggregate sector level to the fundamental firm level.

Empirical research of the globalization decisions by heterogeneous firms, however, has so far been limited, partly constrained by the availability of micro data. Although several studies have examined the exporting-FDI choice (e.g. Head and Ries (2003)), the equally critical question of relative importance between FO and FDI remains empirically unexplored, as far as the author knows. "A firm-level data analysis is needed to answer this question, and no such analysis is available at this point in time” (Antras and Helpman (2004) p.553). This paper provides the direct firm-level evidence on these two choices consistently from the same data set. Since the same firm as a single optimising unit makes both sales and acquisition decisions, a comprehensive investigation encompassing both decisions is important. This paper uses the firm-level data of more than 118 thousand Japanese manufacturers without any firm-size 
thresholds. A large sample size, a comprehensive coverage of the whole manufacturing industries, and a wide range of firm-specific variables, including the direct data of foreign outsourcing, enable our investigation representative, direct, and robust.

This paper is organized as follows. The next section constructs simple theory models to generate testable predictions on the ordering of firm's productivity. Section 3 describes our firm-level data. Additional explanations of the data will be provided in Appendix. Section 4 reports empirical results from the following four methods. First, the average productivity is compared across FO firms, FDI firms, exporters, and domestic firms. Second, the inter-firm distribution of productivity is compared across these groups. Third, industry effects and other relevant factors are controlled by regressions. Finally, multinomial response models of the firm’s choice are estimated. Final remarks are added in Section 5.

\section{Theoretical predictions on firm's productivity}

This section constructs a simple theoretical model to derive a prediction on the relationship between the firm's productivity and her globalization decision. This section considers both the firm’s decision to serve foreign consumers, and the decision to source from foreign suppliers.

\subsection{The decision to serve the foreign market}

This subsection constructs a simple model on the choice between exporting and FDI. The purpose of our formalization is to replicate the testable predictions previously derived by Helpman et al. (2004) in a much simpler, minimal as possible, framework. First, consider a firm maximizing the operating profit $\pi$

$$
\pi=\beta R-w L-f .
$$

A firm bears fixed costs $f$ for starting operations. The inverse of melting-iceberg transport costs 
is denoted by $\beta$, implying that, out of one unit shipped from plants, only the fraction $\beta$, less than one, arrives at consumers. The sales revenue is $R=p q$, where the price and quantity of the final output are denoted by $p$ and $q$, while those of the unique production factor are $w$ and $L$, respectively. The production factor is available following a perfectly elastic supply.

For the production, assume the linear technology: $q=\theta \mathrm{L}$, with $\theta$ as a measure of the productivity. Every industry is populated by heterogeneous firms, which differ in productivity levels. Next, let the inverse demand function be in the following constant-elasticity form: $p=A q^{-1 / 2}$. The constant $A$ is positive. These simplifying assumptions are not intended to confirm reality or generality, but to build a minimal structure generating testable predictions.

From the first-order condition for optimization, the input demand is given by

$$
L=\left(\frac{\beta A}{2 w}\right)^{2} \theta
$$

Naturally, the output is larger when the productivity $\theta$ is higher, the trade $\operatorname{cost} 1 / \beta$ or production cost $w$ is lower, or when the demand $A$ is stronger. The firm earns the profit expressed by

$$
\pi=\frac{\beta^{2}}{w} \theta-f .
$$

The profit function is given by an increasing linear function in productivity. To make expressions simple as possible, we have let $A=2$.

Consider a world with two countries. A firm chooses a channel to access the foreign market: exporting their products from her domestic plants or directly selling overseas production via her foreign affiliates established by FDI. The firm chooses the foreign market access mode (export or FDI) that generates higher profit. ${ }^{1}$ Let the suffix $x$ and $I$ denote exporting and FDI, respectively. A firm bears the fixed costs for global operations in addition to the domestic entry costs $f_{\mathrm{d}}$. Since duplicating production facilities overseas is costly, we can

1 A firm is supposed to decide her globalization mode after observing own productivity level 
safely assume $f_{\mathrm{d}}<f_{x}<f_{\mathrm{I}}$. Besides, since shipping goods across borders requires non-negligible costs for custom clearance, suppose $0<\beta_{x}<\beta_{I}<\beta_{d}<1$. In the trade-off, a firm chooses FDI when the gains from saving variable trade costs outweigh the fixed costs for building plants overseas.

As indicated by these assumptions, the FDI profit line, as the function of productivity in (3), has smaller intercept and steeper slope than the export profit line. This implies that the firm with the productivity lower than the intersection earns higher profits by exporting than FDI but the firm with the productivity higher than the threshold earns more by FDI than exporting in serving the foreign market. ${ }^{2}$ In other words, the productivity of investors must be higher than that of exporters. The profit line for domestic operation has larger intercept and steeper slope, suggesting that all the firms sell at least some outputs at home. ${ }^{3}$ This ordering of productivity is exactly the same as derived from a general model formalized by Helpman et al. (2004). ${ }^{4}$

\subsection{The decision to source from the foreign country}

This subsection addresses the firm's decision of FO vs. FDI to acquire intermediates abroad, basically following Antras and Helpman (2004). ${ }^{5}$ To facilitate comparisons with the previous export vs. FDI model, keep assuming the log-linear demand and linear technology as before. However, to explicitly analyse the sourcing problem, decompose $L$ in the previous model now into two inputs: headquarter services $h$ and manufactured components $m$ with Cobb-Douglas technology $q=\theta \cdot h^{1 / 2} m^{1 / 2}$. The input price for $h$ and $m$ are denoted by $w$ and $r$, respectively. Firms are either final assemblers producing final goods or input suppliers manufacturing

\footnotetext{
2 If the intersection point of the two profit lines takes place at a negative profit level, no firm exports. As exporters and investors coexist in every industry in our sample, this case is assumed away. If the wage in the foreign country is lower than that at home, the slope gap between the export profit line and the FDI profit line becomes even wider, and rather strengthens our result.

3 If the productivity is lower than the threshold for domestic sales, the firm decides to exit.

${ }^{4}$ Head and Ries (2003) offered another simplified model of Helpman et al. (2004). This paper applies our model to the FO choice, which was not explored in Head and Ries (2003).

5 As long as inventory costs are low, a firm can choose sales and procurement independently.
} 
components. Only the final-good producer in the home country can supply headquarter services $h$, while components $m$ are available in both countries, inside and outside the final assembler.

The contract for trading intermediates is inevitably incomplete because signing enforceable complete contracts is generally ex-ante impossible. The contracting party are ex-post involved in the Nash bargaining over the surplus. The fraction of the revenue obtained by the assembler is $\beta(0<\beta<1)$, while the input supplier gains $(1-\beta)$ of the total revenue $R$. Then, the final assembler supplies an amount of headquarter services to maximize $\{\beta R-w h\}$, while the input supplier provides an amount of components to maximize $\{(1-\beta) R-r m\}$ non-cooperatively. As a basic trade-off, higher $\beta$ results in a stronger incentive to provide headquarter services for the assembler, but in a weaker incentive to supply components for the supplier. ${ }^{6}$ By reinterpreting the inverse trade costs $\beta$ as the bargaining power, the previous model is thus applied to this case. By combining the first-order conditions of these two optimization programs, the maximized profit of the assembler is

$$
\pi=3 \sqrt{\frac{\beta(1-\beta)}{w}} \theta-f
$$

, where we have let $A=4$ and $r=1 .^{7}$ The profit function is again linear in productivity $\theta$.

The input supplier is either an independent firm supplying components based on arm's-length contracts (FO), or a foreign affiliate owned by the assembler firm (FDI). ${ }^{8}$ Although the same FDI word is used, the previous subsection examined horizontal FDI duplicating production facilities for final products within the country where final consumers concentrate, but this subsection considers vertical FDI to establish plants manufacturing intermediate inputs, which are finally assembled in domestic production facilities. As indicated

\footnotetext{
6 Antras and Helpman (2004) relate $\beta$ with the industry's technology. However, intra-industry inter-firm variability in bargaining power must be enormous, but is empirically unobservable. 7 We assumed away difference in wages because we have no host country data for empirical studies, but it does not affect our testable predictions, as confirmed in Antras and Helpman (2004).

8 The possibility of domestic sourcing is assumed away for simplification.
} 
by the vast cross-country differences in income, the former should often be located in high-income countries, while the latter are typically found in low-income countries.

Though the friction of incomplete contract exists also within vertically integrated firms, the assembler is supposed to capture larger share in bargaining under FDI than under FO contracts $\left(\beta_{0}<\beta_{\mathrm{I}}\right)$ because vertical integration gives the assembler residual rights, as in Grossman and Hart (1986). ${ }^{9}$ The suffix $O$ and $I$ denote FO and FDI, respectively. Relative to FO, the fixed cost for FDI is high $\left(f_{\mathrm{o}}<f_{\mathrm{I}}\right)$ due to the managerial overload associated with overseas affiliates. The basic trade-off for the assembler in this choice is as follows; FO (FDI, respectively) is less (more) costly in terms of fixed entry cost, but results in a smaller (larger) fraction of revenue.

We find that the slope of the FDI profit line is steeper than that of FO profit line in (4) as long as $\beta<1 / 2{ }^{10}$ This implies, with intercept difference, that the FDI profit exceeds the FO profit if the firm's productivity is higher than the intersection productivity level. As a result of this endogenous sorting, the low-productivity firms outsource while the high-productivity firms insource, among firms acquiring components abroad. This productivity ordering from our model replicates the testable result from the complicated model by Antras and Helpman (2004). ${ }^{11}$

\section{Description of data}

\subsection{Data source}

All the firm-level data used for this paper are derived from the Basic Survey of Commercial and

9 The outside option for input suppliers is always zero, but that of final assembler varies with the organizational choice as vertical integration allows final assembler to use the inputs ex-post.

10 For $1 / 2<\beta<1$, no firm engages in FDI. However, the assumption of assembler's bargaining power so strong is implausible because some firms always choose FDI in every industry.

11 Antras and Helpman (2004) is not the sole model for FO. By considering partial monitoring, Grossman and Helpman (2004) predicts that firms either with high or low productivity choose FO. However, it is difficult to empirically test the hypothesis related with monitoring efforts. Grossman and Helpman (2003) concentrate on the aggregate implications such as market size. 
Manufacturing Structure and Activity (Sho-Kogyo Jittai Kihon Chosa in Japanese). ${ }^{12}$ Detailed description of the data will be given in Appendix. 118,300 firms in all manufacturing industries are surveyed without any firm-size thresholds. This sample size is remarkably large, matched almost only by U.S. Census of Manufacturers. Hence, we can interpret this survey as a good representation of the whole manufacturing in Japan.

Various firm-level data are covered at 1998, such as sales, employment, capital, export share, $R \& D$ expenditure, the number of personal computers used in the firm, and industry classification, for example. For FDI, this survey counts the number of foreign affiliates. Since no data on foreign affiliate's sales/purchases are contained, this paper concentrates on the firm's entry decision in globalization, instead of relying on this count measure of FDI. As the unique and direct data for FO, manufacturing or processing tasks contracted out to foreign firms are captured. ${ }^{13}$ These variables are direct and reasonably informative under usual data constraints.

\subsection{Categorization of firms}

This section categorizes firms by their choice of globalization modes. The share of firms is shown in Figure 1. Since many firms are simultaneously involved in multiple modes, the presentation in a Venn diagram is useful. We note the following points from this figure.

First of all, remarkably large numbers of firms, more than ninety percent of firms, are "domestic" (involved in none of the three activities), though these domestic firms may still be connected with global economies through various channels, such as raw material imports, or international portfolio investment. ${ }^{14}$ Far less than one percent of the firms simultaneously

\footnotetext{
12 This paper focuses on manufacturing, though commercial sectors are also surveyed.

13 While it does not cover outsourcing of non-production services, this definition of FO is more appropriate than those based on import data because the latter include raw materials or intermediates purchased in the marketplace. Tomiura (2004) discusses various FO measures.

14 Since firms with less than fifty employees are sampled with probability less than one in the survey, and since small-sized firms are more likely to be domestic firms, this high share of domestic
} 
engage in all three globalization modes. This finding indicates the existence of non-negligible fixed entry costs for globalization.

Among globalized firms, the FDI share is relatively low. While nearly three percent of the firms directly invest abroad, around six percent are exporters. Though not observable from our data, if FO of non-production services had been covered by the survey, the share of FO firms would have also been higher than that of FDI firms.

\section{Comparisons of productivity at the firm level}

\subsection{Comparison of average productivity}

Table 1 compares the average productivity of firms across different globalization groups. The productivity is measured here in terms of labor productivity (sales divided by the number of employees), ${ }^{15}$ while we will later introduce alternative measures of productivity to check the robustness. The following contrasts emerge from (A) of this table, while the main results remain the same in (B), in which eight categories respond to the mutually disjoint areas in Figure 1.

First, the productivity of investors (firms investing directly abroad) is on average more than twice as high as that of domestic firms. Outsourcers (firms outsourcing across borders) and exporters are located somewhat between these two extreme groups in terms of the productivity ordering. ${ }^{16}$ In terms of the firm size, the gap becomes even larger.

Second, since the labor productivity is affected by variations in capital-labor ratios $(\mathrm{K} / \mathrm{L})$, Table 1 also compares K/L. Again, on average, domestic firms are the least capital-intensive and

firms is a conservative estimate. Since sampling probability is not disclosed, adjusting sampling differences is impossible. Head and Ries (2003) reported that $43 \%$ of Japanese manufacturers are both exporting and investing abroad, but their sample is limited to 1,070 publicly listed firms.

15 Gross output is used to define labor productivity because no data on value-added or costs are available in the survey. To check the robustness, the firm's market share in the home country will be introduced later to consider inter-firm variations in value-added.

16 As this paper focuses on the comparison across different globalization channels, papers on one mode choice (e.g. Bernard and Jensen (2004) on exporting or not) are omitted from the reference. 
investors are the most capital-intensive. Outsourcers are more labor-intensive than exporters, though they are almost the same with exporters both in terms of labor productivity and of firm size. Our finding of labor-intensiveness of outsourcers is consistent with the theoretical prediction by Antras (2003), who shows that the attractiveness of outsourcing contracts compared with vertical integration decreases with the capital-labor ratio because investment cost sharing is relatively easier in physical capital and hiring/managing workers requires local knowledge/management.

As another point to note from (A) of this table, on average, exporters are exporting slightly more than one-tenth of their output, while outsourcers are outsourcing tasks valued around five percent of their output. ${ }^{17}$ The average investor owns nine foreign affiliates.

\subsection{Distribution of productivity}

Though the previous section has compared the average productivity, we should not exclusively depend on average values because cross-section variations are large. ${ }^{18}$ Consequently, this paper presents the cumulative distributions of productivity (the cumulative share of firms in total number for respective productivity levels) in Figure 2. The curves are exact plots, not smoothed approximations.

The cumulative distribution curve of FDI firms is always located to the right of that of domestic firms as well as of exporters and outsourcers in all relevant productivity values, while domestic firms are relatively densely distributed in low productivity ranges. ${ }^{19}$ Hence, the productivity of investors is higher than that of exporters and of outsourcers, both of which in

\footnotetext{
${ }^{17}$ Though the data are not available in the survey, the share of FO value must be higher if we can measure the share relative to total input purchases instead of gross output.

${ }^{18}$ For most variables, the standard deviation is substantially larger than the average. The summary statistics will be available upon request.

19 If we take account of differing sampling probability of the survey, the gap between these two distribution curves must be wider because smaller firms, which are more likely to be domestic firms with lower productivity, are sampled with lower probability.
} 
turn are higher than that of domestic firms, for any relevant range of distributions.

Consequently, our previous finding of higher productivity for investors in terms of average value is robust even when cross-firm distribution is taken account of. This result is also consistent with Girma et al. (2003) finding that the productivity distribution of multinational firms stochastically dominates that of exporters, which in turn dominates that of non-exporters in around five thousand UK manufacturers. Additionally, as far as the author knows, this is the first evidence showing that FDI firms are more productive than FO firms in all relevant ranges of distributions, and that outsourcers and exporters are exerting roughly the same productivity even if their entire distributions are compared.

Since it is not easy to visually discern the productivity gap between exporters and outsourcers from intertwined two curves in Figure 2, we will report values at representative points. Evaluated at the lower ten-percent in the cumulative distribution, the productivity ratio of exporters over domestic firms is 2.3, while that of outsourcers is 2.9. On the other hand, the productivity of investors is more than four times higher than that of domestic firms at this $10 \%$ point (domestic=3.3, $\mathrm{X}=7.5, \mathrm{FO}=9.6, \mathrm{FDI}=13.75$ ). If we look at the median, the gap between exporters and outsourcers diminishes, and the gap between investors and domestic firms also becomes smaller (domestic $=12$ vs. $\mathrm{FDI}=30$ ). At the top $10 \%$ point, the ranking remains almost the same as at the median with even narrower gap (domestic=34, X=54, FO=54, FDI=67).

These distributions also reveal limitations of studies depending on truncated data. Since large-sized firms tend to be productive, any results from data with firm-size thresholds inevitably underestimate the productivity gap. Thus, our firm-level data without any firm-size thresholds is suitable for examining the entire distribution of productivity.

\subsection{Regression estimates}


The previous sections have followed the categorization based on the firm's globalization decision. However, many firms simultaneously engage in more than one globalization modes, as depicted by the Venn diagram in Figure 1. Besides, industry-specific factors are supposed to affect the productivity of firms. For example, the foreign outsourcing is active in some typical labor-intensive industries, such as apparel. Other inter-industry variations are summarized in Table 2. This paper estimates the following regressions to control for these effects. ${ }^{20}$

$$
\mathrm{PROD}_{i}=\alpha+\beta \text { GlobalDUM }_{i}+\gamma \mathrm{IND}+u_{i}
$$

The suffix $i$ indexes the firm. The error term is denoted by $u$. Industry-specific dummies (IND) are included to control for systematic differences across industries. ${ }^{21}$ The dummy GlobalDUM, of which the definition will be explained shortly, considers firms active in multiple globalization modes. The regression (5) should be viewed as a compact way to identify the average productivity taking account of overlaps and industry effects.

For the productivity $P R O D$, this paper uses four alternative measures: labor productivity $(Q / L)^{22}$, Approximate Total Factor Productivity $(A T F P)^{23}$, the firm's market share in the home country and the firm size $(Q)$, all in logarithm. The firm size in terms of output can be served as a proxy for the productivity since output $x$ systematically increases with productivity $\theta$ in our simple model. The domestic market share of a firm also has a monotonic positive relation with the firm's productivity in most standard models of this genre. The use of the market share in the home country has an advantage as a productivity proxy in that it avoids assuming constant mark-ups across firms. Finally, ATFP is defined by, basically adjusting the labor productivity

\footnotetext{
20 Head and Ries (2003) compare investors vs. exporters by the basically same regressions.

21 Industry dummies are defined at the two-digit level, as seriously limited numbers of firms exist in some three-digit industries.

22 The results from the labor productivity controlling for inter-firm variations in $K / L$ are very close to those from ATFP, and thus omitted from Table 3, but will be available upon request.

23 See Griliches and Mairesse (1990), and Head and Ries (2003) for ATFP.
} 
for differing capital-labor ratio, ${ }^{24} A T F P=(\ln Q / L)-(\ln K / L) / 3$.

The vector of the firm-specific dummy variables $\{X, O, H, L\}$ and all combinations of their interactive terms are summarized by GlobalDUM in (5). We define $X$ to take one for exporters, and zero for non-exporters. Similarly, $O, H$, and $L$ are the dummies for outsourcers, firms having FDI in high-income countries, and firms investing in low-income countries, respectively. Regarding destinations of FDI, Asia is considered separately from the rest of the world in the survey, while no further geographical disaggregation is available. Hence, this paper calls Asia and the rest of the world as "low-income countries" and "high-income countries" respectively, because FDI from Japan predominantly go either into U.S., E.U., or Asia.

The productivity estimates, expressed in the log-difference from that of domestic firms, are summarized in Table 3. Standard errors are reported in heteroskedasticity-robust estimates. The figures in the table are after summing over all related statistically significant coefficients, including interactive terms. ${ }^{25}$ For example, for $\mathrm{XOH}$, we add the estimated coefficients on $\mathrm{X}, \mathrm{O}$, $\mathrm{H}$, as well as on $\mathrm{XO}, \mathrm{OH}, \mathrm{XH}$, and on $\mathrm{XOH}$. The ordering is basically robust across alternative productivity measures. Important findings are as follows.

First, exporters without other globalization modes tend to be among the least productive within globalized firms, as predicted by our theory model and consistent with previous empirical results (e.g. Head and Ries (2003)). ${ }^{26}$

Second, while they are not more productive than the firms globalized only through exporting, FO firms are ranked relatively high in terms of ATFP, as consistent with our previous finding of labor-intensiveness of outsourcers, predicted by Antras (2003).

24 The choice of $1 / 3$ does not affect our results, as we have tried alternative values (1/4). Estimating true TFP for each firm is difficult in our cross-section format.

25 All the coefficients with t-value larger than two are added, but even if all the coefficients irrespective of its significance are summed, the productivity ranking is not considerably different. 26 Brainard (1997) reported that the share of exports relative to FDI sales increases with economies of scale at the industry-level, but the productivity comparison was not her main focus. 
Third, the firms investing in high-income countries tend to be more productive than firms with FDI only in low-income countries. The firms investing only in low-income countries tend to be less productive than other globalized firms, but they are undoubtedly more productive than domestic firms. These findings are consistent with the theory model by Head and Ries (2003) incorporating differences in income levels. ${ }^{27}$

Finally, the firms simultaneously engaged in more than one globalization modes tend to be relatively productive. This result corroborates the previous empirical finding by Head and Ries (2003), though theoretical models suggest that the most productive firms engage only in FDI. To explain this empirical regularity, we will need in the future to theoretically formalize multiple foreign countries with different cost conditions.

\subsection{Firm's choice and productivity}

Previous statistical sections have not paid serious attentions to the decision of the individual firm. Consequently, this section uses the multinomial response model because, in the sourcing decision, a firm is supposed to choose from the following four alternatives: (a) outsourcing to independent foreign suppliers, (b) purchasing from her own foreign affiliates established by FDI, (c) sourcing both from foreign outsourcing and FDI affiliates, or (d) sourcing totally from domestic suppliers. In the sales decision, similarly, the four choices available for a firm are as following: (a) directly exporting the products manufactured at home, (b) serving foreign markets by the products supplied from foreign affiliates established by FDI, (c) serving foreign markets both by exporting and FDI, or (d) selling all products in the home country.

Since it is practically impossible to distinguish FDI for sales from FDI for sourcing, and since horizontal FDI replacing exports tends to be concentrated in high-income countries and

27 Our result is stronger than Head and Ries (2003) in that, not only firms investing in high-income countries, but also firms investing in low-income countries have higher productivity than exporters. 
vertical FDI supplying intermediates is typically located in neighbouring low-income countries, this paper assumes that FDI compared with FO in the firm's input sourcing decision is FDI in low-income countries (Asia), and that FDI in the sales decision is FDI in high-income countries. ${ }^{28}$ Given the limited availability of firm-level data on intra-firm trade, this approximation is consistent with daily observations of active intra-Asia trade in intermediates and many Japanese-owned plants in U.S. or in E.U. replacing exports from Japan. ${ }^{29}$

Table 4 reports results from the following multinomial logit model:

$$
P(y=j \mid x)=\exp \left(x \beta_{j}\right) /\left(1+\sum_{h=1}^{3} \exp \left(x \beta_{h}\right)\right) \quad(j=1,2,3)
$$

, where the globalization mode choice of the firm is denoted by $y$. The base category $(y=0)$ is the domestic option (no globalization). The characteristics of the firm, including productivity, are summarized by the vector $x$. The theoretical motivation of using this distributional form can be sought in the optimisation by the firm choosing from alternatives. The results for the firm's sourcing choice are shown in the first two columns, while those for sales decision are shown in the columns (3) and (4) of the table. Standard errors are evaluated by hetroskedasticity-consistent estimates. The results with and without industry-specific dummies are reported. The explanatory variables included in the right-hand side of (6) are the labor productivity, the capital-labor ratio, the R\&D intensity (R\&D-sales ratio), and the number of personal computers used in the firm relative to the firm size (in terms of sales). ${ }^{30}$ All these variables are supposed to induce firms to choose globalization, while most of them are supposed to be endogenous. Within our cross-section data set, however, it is practically difficult to find appropriate instruments. Hence, our results should not be interpreted as causality. The

\footnotetext{
28 In our survey, intra-firm trade between FDI affiliates and parent firms could be included in FO.

29 We have confirmed that the principal results reported below are robust even if both FDI in Asia and FDI in ROW are replaced by total FDI.

${ }^{30}$ All are in logarithm. Before taking logarithm, we add one to the R\&D intensity and to the computer-usage intensity because many firms conduct no R\&D or have no computers.
} 
noteworthy points are as follows.

First, almost all the explanatory variables are strongly significant. The response probability of the choice $j$ relative to the base category (domestic operation only) is equal to $p_{j} / p_{0}=\exp \left(x \beta_{j}\right)$. Our finding of $\beta$ positive shows that a firm is more likely to globalize when the firm is more productive, more innovative, or more computerized. To get a sense of economic significance of estimates, we can also calculate how much the relative response probability $\left(p_{j} / p_{0}\right)$ is affected by productivity changes. For example, a ten-percent increase in productivity is associated with the increase in this odd-ratio of the globalization only through FDI by 9.9 percent in the decision vs. exporting, and by 9.3-9.4 percent in the decision vs. FO, respectively. Thus, the impact of productivity on the firm's globalization is rather sizable. ${ }^{31}$

Second, regarding the effect of capital-labor ratio, a firm is more likely to choose FO when the firm's products are more labor intensive, as theoretically predicted by Antras (2003). However, its statistical significance is lost when industry effects are controlled. This difference by industry dummies partly reflects the inter-industry variation that FO tends to be active in labor-intensive industries, such as apparel. On the other hand, a firm tends to prefer FDI or exporting to domestic sales when her capital-labor ratio is high, possibly due to the Japan's comparative advantage for export or the capital requirement for FDI.

Various differences within globalized firms have also emerged. In the multinomial logit model, the log-odds ratio of any two choices $j$ and $h$ is $\log \left\lfloor p_{j} / p_{h}\right\rfloor=x\left(\beta_{j}-\beta_{h}\right)$.

First, in the sales decision, when a firm compares exporting vs. FDI, more productive firms are more likely to choose FDI over exporting, as predicted by the theory. On the other

\footnotetext{
${ }^{31}$ We have also estimated alternative models: three binary-choice models (e.g. export or not), and the ordered logit model (investors must be more productive than exporters/outsourcers, followed by domestic firms), and confirmed the robustness. The nested logit model (firms choosing global or domestic in the first stage, then, choosing FDI, FO/exporting, or both in the second stage), however, was not tried due to computer capacity.
} 
hand, in the purchase decision, more productive firms no more significantly choose FDI over FO in our case. However, our estimates imply that the high-productivity firms tend to prefer the globalization both through FDI and FO/exporting simultaneously rather than choosing only one of the either, as consistent with our previous regression findings reported in Table $3 .^{32}$

Similarly, for other explanatory variables, several interesting regularities are also found. Active R\&D tends to induce firms to choose FDI over FO/exporting. This finding is consistent with our prior that innovative tasks are difficult to be contracted out and thus internalized. Active use of computers tends to result in FO than FDI, and exporting is the least information-technology intensive. This result is also plausible because contracting with suppliers in remote locations requires high communication skills/costs.

\section{Concluding remarks}

This paper has examined both the firm's decision of export vs. FDI to serve foreign consumers and the decision of FO vs. FDI to source from foreign suppliers. The firm-level data of 118,300 manufactures without firm-size thresholds are exploited, though outsourcing of non-production services, FDI host country factors, or intra-firm trade are not captured in the survey.

Empirical results support our theoretical predictions. In particular, FDI firms are distinctively more productive than firms outsourcing overseas, which are roughly comparable with exporters, and in turn are more productive than domestic firms. This ordering of productivity has been confirmed robust, even after controlling for industry effects, and considering inter-firm distributions. Thus, this paper has provided direct evidence for the empirical relevance of the heterogeneous firm model in international trade.

32 Kurz (2004) included the exporter dummy in the regression of his FO dummy, defined by material imports, but exporting and outsourcing are separate and simultaneous decisions. 


\section{Acknowledgement}

The Ministry of Public Management allowed the author to have access to micro-data files by the approval No. 428. The author appreciates helps by Kazuyuki Motohashi and Junko Sakamoto for the data access, and the encouragement by Seiichi Katayama for initiating this work. An earlier version of this paper was presented at international conferences at Kobe and Yokohama. The author acknowledges valuable comments from participants, especially Stephan Yeaple. This research was partly financed by Japan Economic Research Promotion Foundation and Grant-in-Aid for Scientific Research (Nos. B14330012, C13630056, and C16530152). Remaining errors are mine.

\section{Appendix}

All the firm-level data are derived from the Basic Survey of Commercial and Manufacturing Structure and Activity (Sho-Kogyo Jittai Kihon Chosa in Japanese). Any researcher can have access to the same firm-level data as long as she/he obtains individual official permission from the government in advance. The government has no plan to continue this survey in the same format. Although the survey is not a census, the sample is intended to be representative of the population of all firms. While all the firms with fifty or more employees are surveyed with certainty, firms with less than fifty employees are sampled with varying probability. The government does not release the sampling probability for each industry-size cell.

The used variables are as follows. The employment $(L)$ is the number of "total regular employees.” The output, $Q$, is "sales value,” while no data on value-added or costs are reported. The capital, $K$, is the value of "tangible fixed asset." The number of foreign affiliates is the only FDI data in the survey. This paper focuses on foreign affiliates with ownership shares no less than $20 \%$ because those less than $20 \%$ are not recognized with destination disaggregation and may be contaminated by portfolio investment. For FO, the survey literally asks "contracting out (gaichu, in Japanese) of manufacturing or processing tasks to other firms," explicitly distinguishing contracts with firms located overseas from those inside Japan.

\section{References}

Antras, P. (2003) "Firms, contracts, and trade structure," Quarterly Journal of Economics 118, 1375-1418.

Antras, P., and Helpman, E. (2004) "Global sourcing," Journal of Political Economy 112, 552-580.

Bernard, A., and Jensen, B. (2004) "Why some firms export," Review of Economics and Statistics 86, 561-569.

Bernard, A., Eaton, J., Jensen, B., and Kortum, S. (2003) "Plants and productivity in 
international trade,” American Economic Review 93, 1268-1290.

Brainard, L. (1997) “An empirical assessment of the proximity-concentration trade-off between multinational sales and trade,” American Economic Review 87, 520-544.

Girma, S., Keller, R., and Pisu, M. (2003) "Export versus FDI: an empirical test," Research Paper No. 2003/21, Leverhulme Center for Research on Globalisation and Economic Policy, University of Nottingham.

Griliches, Z., and Mairesse, J. (1990) "R\&D and productivity growth: comparing Japanese and US manufacturing firms,” in Hulten, C. ed. Productivity Growth in Japan and the United States, The University of Chicago Press, Chicago, pp.317-340.

Grossman, G., and Hart, O. (1986) "The costs and benefits of ownership: a theory of vertical and lateral integration,” Journal of Political Economy 94, 691-719.

Grossman, G., and Helpman, E. (2003) “Outsourcing versus FDI in industry equilibrium,” Journal of the European Economic Association 1, 317-327.

Grossman, G., and Helpman, E. (2004) "Managerial incentives and the international organization of production,” Journal of International Economics 63, 237-262.

Head, K., and Ries, J. (2003) "Heterogeneity and the FDI versus export decision of Japanese manufacturers,” Journal of the Japanese and International Economies 17, 448-467.

Helpman, E., Melitz, M., and Yeaple, S. (2004) "Export versus FDI with heterogeneous firms,” American Economic Review 94, 300-316.

Kurz, C. (2004) "Outstanding outsourcers: a firm and plant-level analysis of production sharing,” downloaded from http://www.eiit.org/ConfInfo/program04.doc.

Tomiura, E. (2005) "Foreign outsourcing and firm-level characteristics: evidence from Japanese manufacturers,” Journal of the Japanese and International Economies, forthcoming. 
Table 1 Comparison of average productivity

(A)

\begin{tabular}{|c|c|c|c|c|}
\hline & Domestic & F. Out $(O)$ & Export $(X)$ & FDI $(I)$ \\
\hline Productivity $(Q / L)$ & 17.3 & 28.8 & 29.5 & 38.1 \\
\hline Firm size $(Q)$ & 892 & 23,465 & 22,935 & 52,069 \\
\hline K/L & 6.4 & 7.8 & 9.5 & 11.6 \\
\hline FO/Q (\%) & 0 & 5.2 & 5.4 & 7.1 \\
\hline Export/Q (\%) & 0 & 17.7 & 10.8 & 17.5 \\
\hline FDI & 0 & 11 & 10 & 9 \\
\hline \# Firms & 107,241 & 3,163 & 7,479 & 3,501 \\
\hline
\end{tabular}

(B)

\begin{tabular}{|c|r|r|r|r|}
\hline & Productivity & \multicolumn{1}{|c|}{ Firm Size } & \multicolumn{1}{|c|}{ K/L } & \multicolumn{1}{c|}{ Share (\%) } \\
\hline O only & 1.42 & 2.25 & 1.09 & 1.70 \\
\hline$X$ only & 1.46 & 4.48 & 1.38 & 4.38 \\
\hline$I$ only & 2.08 & 31.11 & 1.91 & 1.07 \\
\hline$O^{*} X$ & 1.88 & 25.60 & 1.17 & 0.30 \\
\hline$X^{*} I$ & 2.30 & 66.01 & 1.90 & 1.22 \\
\hline$I^{*} O$ & 1.94 & 16.86 & 1.33 & 0.25 \\
\hline$O^{*} X^{*} I$ & 2.32 & 130.88 & 1.68 & 0.42 \\
\hline Domestic & 1 & 1 & 1 & 90.65 \\
\hline
\end{tabular}

Notes: The labor and FDI are counted by the number of regular employees and of foreign affiliates, respectively, but other variables are originally measured in million yen in (A). The share is in the number of firms, but other variables are expressed relative to domestic firms in (B). Firms are included in all relevant categories in (A), but each category is mutually exclusive in (B). 
Table 2 Comparison across industries

\begin{tabular}{|c|c|c|c|}
\hline & $\begin{array}{c}\text { (1) } \\
\text { F. Out }\end{array}$ & $\begin{array}{c}(2) \\
\text { Export }\end{array}$ & $\begin{array}{c}(3) \\
\text { FDI }\end{array}$ \\
\hline 13. Beverage, Tobacco \& Feed & 0.36 & 1.31 & 1.17 \\
\hline 14. Textile & 0.73 & 1.32 & 1.72 \\
\hline 15. Apparel \& Textile products & 2.55 & 0.76 & 2.32 \\
\hline 16. Timber \& Wooden products & 0.78 & 0.41 & 0.92 \\
\hline 17. Furniture \& fixture & 1.08 & 0.70 & 1.29 \\
\hline 18. Pulp \& Paper products & 0.75 & 1.66 & 1.47 \\
\hline 19. Printing \& Publishing & 0.84 & 1.19 & 1.29 \\
\hline 20. Chemical products & 1.28 & 16.14 & 7.60 \\
\hline 21. Petroleum \& Coal products & 0.83 & 7.46 & 5.80 \\
\hline 22. Plastic products & 1.16 & 5.30 & 4.08 \\
\hline 23. Rubber products & 2.34 & 5.27 & 2.97 \\
\hline 24. Leather \& Fur products & 3.28 & 2.30 & 0.98 \\
\hline 25. Ceramic, Stone \& Clay products & 0.71 & 3.95 & 1.60 \\
\hline 26. Iron \& Steel & 1.23 & 6.90 & 3.16 \\
\hline 27. Nonferrous Metals & 1.09 & 8.13 & 4.90 \\
\hline 28. Metal products & 0.92 & 5.36 & 2.02 \\
\hline 29. General Machinery & 2.37 & 11.18 & 4.30 \\
\hline 30. Electric Machinery & 3.08 & 10.54 & 5.07 \\
\hline 31. Transportation Equipment & 1.99 & 8.94 & 5.54 \\
\hline 32. Precision Instruments & 2.73 & 10.71 & 3.01 \\
\hline 34. Miscellaneous manufacturing & 3.49 & 6.77 & 3.62 \\
\hline
\end{tabular}

Notes: Shown are the estimated coefficients (multiplied by 100) on industry dummies. In the regression of the globaloization mode dummy as the dependent variable, industry dummies are the only regressors. Values are relative to the food manufacturing industry (12). The ordnance (33) is merged into the general machinery (31). All 118,300 firms are included. 
Table 3 Productivity comparison based on regression estimates

\begin{tabular}{|c|c|c|c|c|}
\hline Rank & (1) $Q / L$ & (2) Firm size & $\begin{array}{c}\text { (3) Home } \\
\text { market share }\end{array}$ & (4) ATFP \\
\hline 1 & $\begin{array}{c}\mathrm{XOH} \\
(2.803)\end{array}$ & $\begin{array}{c}X O H L \\
(6.664)\end{array}$ & $\begin{array}{l}\text { XOHL } \\
(6.392)\end{array}$ & $\begin{array}{c}\mathrm{OH} \\
(0.882)\end{array}$ \\
\hline 2 & $\begin{array}{c}\text { XOHL } \\
\text { (1.388) }\end{array}$ & $\begin{array}{c}X H L \\
(5.336)\end{array}$ & $\begin{array}{c}X H L \\
(5.073)\end{array}$ & $\begin{array}{c}X O H \\
(0.803)\end{array}$ \\
\hline 3 & $\begin{array}{c}\text { OHL } \\
(1.297)\end{array}$ & $\begin{array}{c}H L \\
(4.994)\end{array}$ & $\begin{array}{c}H L \\
(4.992)\end{array}$ & $\begin{array}{c}\text { XOHL } \\
(0.750)\end{array}$ \\
\hline 4 & $\begin{array}{c}\text { XHL } \\
(1.217)\end{array}$ & $\begin{array}{c}\text { OHL } \\
(4.618)\end{array}$ & $\begin{array}{c}\text { OHL } \\
(4.617)\end{array}$ & $\begin{array}{c}\text { OHL } \\
(0.676)\end{array}$ \\
\hline 5 & $\begin{array}{c}H L \\
(1.206)\end{array}$ & $\begin{array}{c}\mathrm{XOH} \\
(4.317)\end{array}$ & $\begin{array}{c}\mathrm{XOH} \\
(4.007)\end{array}$ & $\begin{array}{c}\text { XHL } \\
(0.647)\end{array}$ \\
\hline 6 & $\begin{array}{c}\mathrm{OH} \\
(1.148)\end{array}$ & $\begin{array}{c}X H \\
(3.738)\end{array}$ & $\begin{array}{c}X H \\
(3.502)\end{array}$ & $\begin{array}{c}X O \\
(0.606)\end{array}$ \\
\hline 7 & $\begin{array}{c}X O \\
(0.962)\end{array}$ & $\begin{array}{c}H \\
(3.399)\end{array}$ & $\begin{array}{c}H \\
(3.399)\end{array}$ & $\begin{array}{c}H L \\
(0.582)\end{array}$ \\
\hline 8 & $\begin{array}{c}X O L \\
(0.960)\end{array}$ & $\begin{array}{c}X O L \\
(3.201)\end{array}$ & $\begin{array}{c}\mathrm{OH} \\
(3.142)\end{array}$ & $\begin{array}{c}O \\
(0.487)\end{array}$ \\
\hline 9 & $\begin{array}{c}X H \\
(0.931) \\
\end{array}$ & $\begin{array}{c}X L \\
(3.161) \\
\end{array}$ & $\begin{array}{c}X O L \\
(3.036)\end{array}$ & $\begin{array}{c}O L \\
(0.484)\end{array}$ \\
\hline 10 & $\begin{array}{c}H \\
(0.896)\end{array}$ & $\begin{array}{c}\mathrm{OH} \\
(3.141)\end{array}$ & $\begin{array}{c}X L \\
(3.032)\end{array}$ & $\begin{array}{c}X H \\
(0.428)\end{array}$ \\
\hline 11 & $\begin{array}{c}O L \\
(0.868)\end{array}$ & $\begin{array}{c}X O \\
(2.845)\end{array}$ & $\begin{array}{c}L \\
(2.690)\end{array}$ & $\begin{array}{c}X L \\
(0.397)\end{array}$ \\
\hline 12 & $\begin{array}{c}X L \\
(0.823)\end{array}$ & $\begin{array}{c}L \\
(2.690)\end{array}$ & $\begin{array}{c}X O \\
(2.630)\end{array}$ & $\begin{array}{c}H \\
(0.395)\end{array}$ \\
\hline 13 & $\begin{array}{c}L \\
(0.811)\end{array}$ & $\begin{array}{c}O L \\
(2.539)\end{array}$ & $\begin{array}{c}O L \\
(2.540)\end{array}$ & $\begin{array}{c}L \\
(0.390)\end{array}$ \\
\hline 14 & $\begin{array}{c}O \\
(0.788)\end{array}$ & $\begin{array}{c}X \\
(1.856)\end{array}$ & $\begin{array}{c}X \\
(1.742)\end{array}$ & $\begin{array}{c}X O L \\
(0.379)\end{array}$ \\
\hline 15 & $\begin{array}{c}X \\
(0.489) \\
\end{array}$ & $\begin{array}{c}O \\
(1.666)\end{array}$ & $\begin{array}{c}O \\
(1.667) \\
\end{array}$ & $\begin{array}{c}X \\
(0.231) \\
\end{array}$ \\
\hline 16 & $\begin{array}{c}\text { Domestic } \\
(0)\end{array}$ & $\begin{array}{c}\text { Domestic } \\
(0)\end{array}$ & $\begin{array}{c}\text { Domestic } \\
(0)\end{array}$ & $\begin{array}{c}\text { Domestic } \\
(0)\end{array}$ \\
\hline \# Firms & 118,300 & 118,300 & 118,219 & 95,645 \\
\hline
\end{tabular}

Notes: Groups of firms are arrayed in descending order of productivity. Shown in parentheses are the productivity measured in terms of the logarithm difference from that of the domestic firms, after controlling for industry effects. The productivity estimates are the summation over all significant coefficient estimates on dummies including all related interactive terms. The measure for productivity is shown in the first row of each column. 
Table 4 Estimation results of the firm's choices

\begin{tabular}{|c|c|c|c|c|}
\hline & $\begin{array}{c}(1) \\
O \text { vs. } L\end{array}$ & $\begin{array}{c}(2) \\
O \text { vs. } L\end{array}$ & $\begin{array}{c}\text { (3) } \\
X \text { vs. } H \\
\end{array}$ & $\begin{array}{c}(4) \\
X \text { vs. } H \\
\end{array}$ \\
\hline (a) $O$ only, $X$ only & 0.980 & 0.923 & 0.628 & 0.605 \\
\hline Productivity & $(0.034)$ & $(0.033)$ & $(0.022)$ & $(0.020)$ \\
\hline \multirow[t]{2}{*}{$\mathrm{K} / \mathrm{L}$} & 0.012 & -0.097 & 0.150 & 0.114 \\
\hline & $(0.024)$ & $(0.022)$ & $(0.014)$ & $(0.013)$ \\
\hline \multirow[t]{2}{*}{$\mathrm{R} \& \mathrm{D}$} & 7.107 & 8.491 & 8.857 & 12.545 \\
\hline & $(0.978)$ & (1.104) & $(0.838)$ & (1.020) \\
\hline \multirow[t]{2}{*}{ Computers } & 2.007 & 2.503 & 0.454 & 2.688 \\
\hline & $(0.763)$ & $(0.486)$ & $(0.930)$ & (1.245) \\
\hline \multirow{2}{*}{$\begin{array}{l}\text { (b) FDI only }(L, H) \\
\text { Productivity }\end{array}$} & 0.939 & 0.928 & 0.991 & 0.988 \\
\hline & $(0.026)$ & $(0.025)$ & $(0.056)$ & $(0.054)$ \\
\hline \multirow[t]{2}{*}{$\mathrm{K} / \mathrm{L}$} & 0.336 & 0.277 & 0.485 & 0.453 \\
\hline & $(0.018)$ & $(0.017)$ & $(0.046)$ & $(0.045)$ \\
\hline \multirow[t]{2}{*}{$\mathrm{R} \& \mathrm{D}$} & 7.878 & 9.427 & 10.686 & 13.851 \\
\hline & $(1.226)$ & (1.354) & (1.145) & $(1.290)$ \\
\hline \multirow[t]{2}{*}{ Computers } & 1.784 & 2.322 & 2.471 & 3.509 \\
\hline & $(0.491)$ & $(0.465)$ & $(0.362)$ & (1.455) \\
\hline \multirow{2}{*}{$\begin{array}{r}\text { (c) Both }(O L, X H) \\
\text { Productivity }\end{array}$} & 1.149 & 1.067 & 1.361 & 1.233 \\
\hline & $(0.042)$ & (0.038) & $(0.037)$ & $(0.031)$ \\
\hline \multirow[t]{2}{*}{$\mathrm{K} / \mathrm{L}$} & 0.278 & 0.141 & 0.493 & 0.388 \\
\hline & $(0.029)$ & $(0.026)$ & $(0.024)$ & $(0.021)$ \\
\hline \multirow[t]{2}{*}{ R\&D } & 8.649 & 9.829 & 13.766 & 17.078 \\
\hline & (1.265) & (1.410) & (1.741) & (1.799) \\
\hline \multirow[t]{2}{*}{ Computers } & -1.535 & 2.422 & 2.526 & 4.058 \\
\hline & (1.644) & $(0.494)$ & $(0.470)$ & $(1.430)$ \\
\hline Industry Dummies & Yes & No & Yes & No \\
\hline \multirow[t]{4}{*}{ Statistics } & Log likelihood & Log likelihood & Log likelihood & Log likelihood \\
\hline & $=-17931.113$ & $=-18817.823$ & $=-24315.837$ & $=-26392.921$ \\
\hline & Pseudo $\mathrm{R}^{2}$ & Pseudo $\mathrm{R}^{2}$ & Pseudo $\mathrm{R}^{2}$ & Pseudo $\mathrm{R}^{2}$ \\
\hline & $=0.1268$ & $=0.0837$ & $=0.1544$ & $=0.0822$ \\
\hline
\end{tabular}

Notes: The number of firms is 95,645. Each equation is estimated by multinomial logit. Heteroskedasticity-robust estimated standard errors are in parentheses. The available choices in the first two columns are FO, FDI in Asia, both FO and FDI, and domestic sourcing, while those in the last two columns are exporting, FDI in high-income countries, both exporting and FDI, and domestic sales. Explanatory variables, except industry dummies, are in logarithm. 
Figure 1 Share of firms with various globalization modes

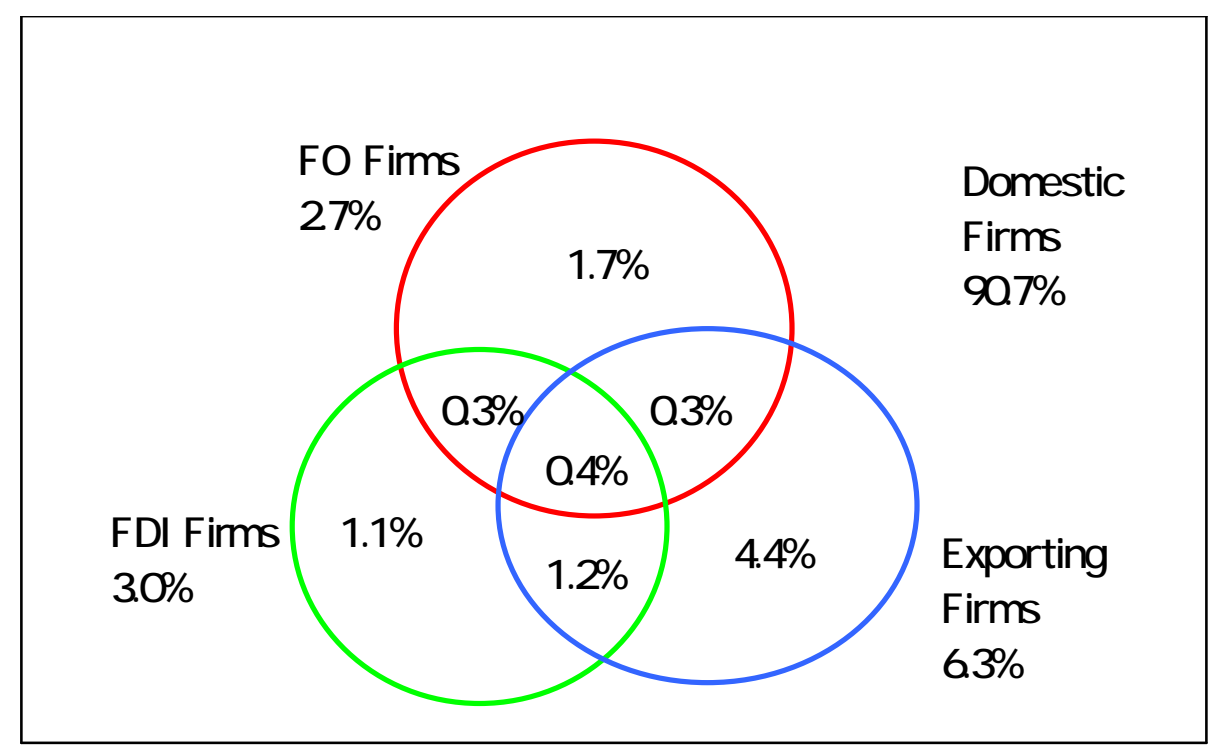

Notes: All percentage shares are relative to the total number of firms (118,300 firms). Areas are not shown proportional to the number of firms. 
Figure 2

Cumulative Distribution of Productivity

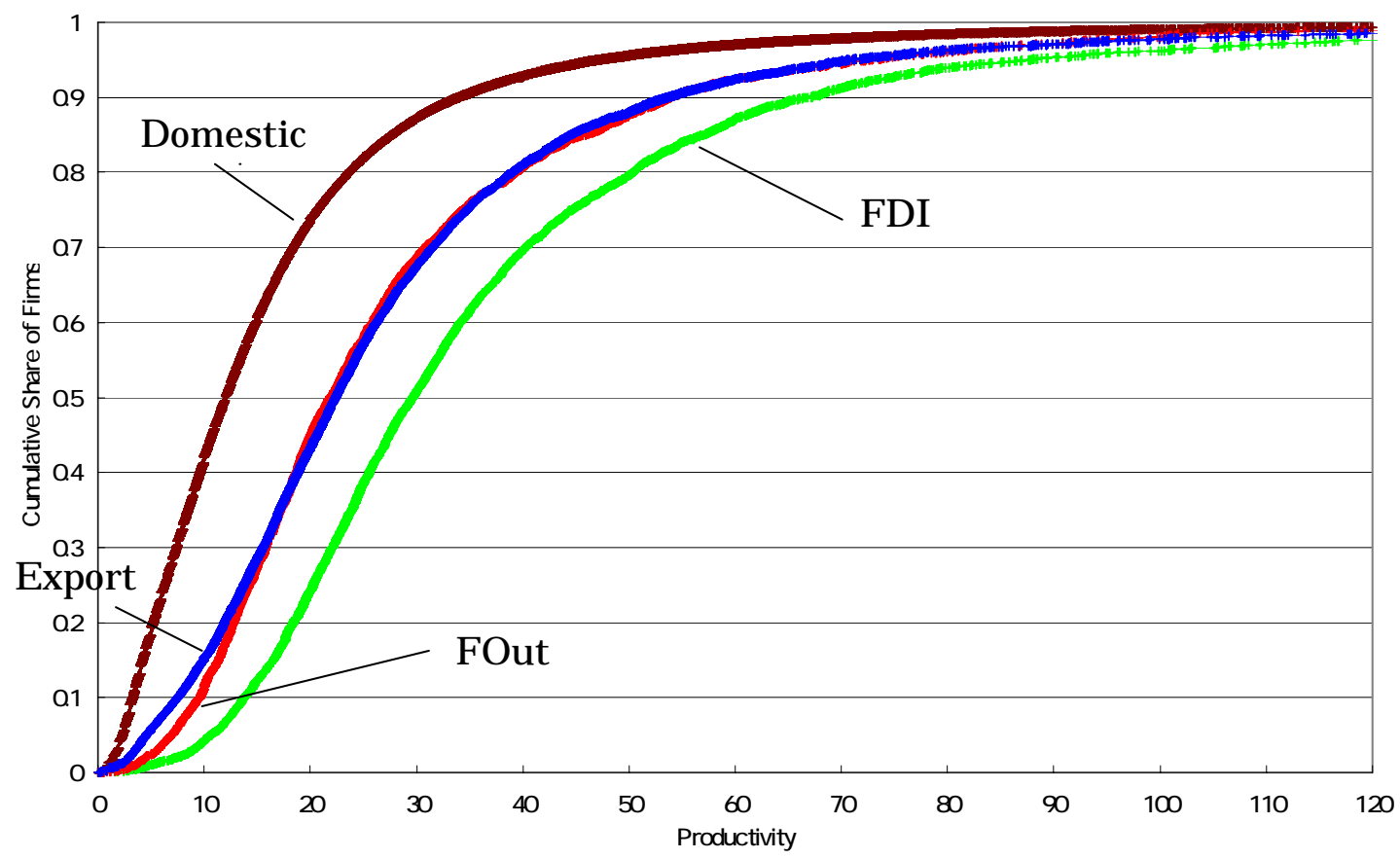

(Notes) All the firms are arrayed on the ascending order of productivity in each group. The labor productivity is measured on the horizontal axis, while the cumulative share of the number of firms is measured on the vertical axis. 